\title{
Biomechanics and numerical evaluation of cervical porcine models considering compressive loads using 2-D classic computer tomography CT, 3-D scanner and 3 -D Computed Tomography
}

\author{
J.A. Beltran-Fernández ${ }^{1 \mathrm{a}}$, L.H. Hernández-Gómez ${ }^{1 \mathrm{~b}}$, \\ G. Urriolagoitia-Calderón ${ }^{1 \mathrm{c}}, \mathrm{A}$. González-Rebatú ${ }^{2 \mathrm{~d}}, \mathrm{G}$. Urriolagoitia-Sosa ${ }^{1 \mathrm{e}}$ \\ ${ }^{1}$ Instituto Politécnico Nacional, Escuela Superior de Ingeniería Mecánica y Eléctrica (ESIME) \\ Unidad Zacatenco. Sección de Estudios de Posgrado e Investigación, ESIME Zacatenco, Unidad \\ Profesional Adolfo López Mateos (UPALM), Edificio 5, 3er Piso, 07738, D.F., México. \\ Tel.: 5729-6000, ext.: 54691 \\ ${ }^{2}$ Hospital Regional ISSSTE 1ํ de Octubre, Av. Instituto Politécnico Nacional. Núm. 1669, \\ Col. Magdalena de las Salinas, 07760, México. \\ ajbeltranf@hotmail.com, 'luishector56@hotmail.com, currio332@hotmail.com, \\ djanosclub@hotmail.com, ${ }^{e}$ guiurri@hotmail.com
}

Keywords: Biomechanics, cervical, 3-D Scanning, Compressive loads, Porcine vertebrae

\begin{abstract}
In this paper the biomechanical behavior and numerical evaluation results of three C3-C5 porcine cervical models created with different modeling techniques are shown. The objective of this evaluation is to know the differences between the biomechanical effects on a bone graft, which replaces a damaged $\mathrm{C} 4$ vertebral body, a titanium alloy (Ti-6A1-4V) cervical plate, used to isolate the C4 damaged vertebra, and the influence on the compressive loads on the complete and instrumented C3-C5 cervical model. The biomechanical integrity of the healthy C3 and C5 vertebral body after the fixation of the cervical plate using titanium alloy screws is considered. Besides, 2-D Computer Tomography classic technique, 3-D Scanner Z-Corp 700 and a CT scanning Philips Brilliance system was used to create the three FEM models. In addition, 3-D Software as Pro-E Wildfire 4.0, ScanIP 3.1, UGS NX-4 and Geomagics R 10.0 was used to create specific numerical model. Main displacements and von Misses stresses between the upper and lower surfaces of the vertebral bodies and the bone graft and the influence of the titanium alloy (Ti-6A1-4V) screws on the vertebral body of C3 and C5 were evaluated. The contribution of this study is to optimize the actual surgical technique once the numerical results on the FEM model have been analyzed. In other words, the numerical disparity between classic CT techniques versus 3-D modern techniques is established.
\end{abstract}

\subsection{Introduction}

At the present time, modeling techniques has changed using modern techniques which are useful in order to create complex geometries. The beginning of CAD Software and the evolution of the parametric engineering computer software has transformed the way in which the classic engineering problems are solved using structural parts. However, medical surgeries requires different solutions including complex conditions to evaluate new prosthesis or methodology using the engineering and medical analysis in order to know the mechanical and natural behavior of organic structures as bone, ceramic, titanium alloy and soft tissue, used in the cervical spine.

Diverse publications about advanced modeling techniques using CAD/CAE tools does not define the affinity between the real and the virtual model, especially in human and organic structures considering tissue, bone and the complexity of the surfaces. However, important results in orthopaedic and biomechanics studies are reported and classified in at least two substantial reviews, the first covering "the first decade" by Huiskes and Chao [1] in 1983 and the second by Prendergast [2] in 1972. Finite element modelling in cardiovascular biomechanics has not been reviewed in this way. Some of the principal aspects are discussed by Holzapfel and Ogden [3], and a review of cardiovascular stenting is given in Lally \& et al [4]. Van der Meulen and Huiskes [5] have 
presented a survey of mechanobiology, including computational approaches, and recently Panjabi \& et al. [7] using diverse biomechanics models with numerical and experimental analysis.

In this case, the present work focuses on the cervical spine, studying its mechanical behavior considering the natural state and extreme external forces caused by fracture mechanism and specific trauma evaluated by specialist medics on human spine in Mexican Hospitals as a part of medical rehabilitation programs. Medical institution is referred to ISSSTE Regional Hospital " ${ }^{\circ}$ de Octubre" and Academic Research Institute by the National Polytechnic Institute, and financed by The National Council for Science and Technology, CONACYT, Mexico. Numerical testing using compression loading over porcine specimens instrumented with cervical plate and bone graft were reported by Beltran $[8,9]$ using a FEM Model created by classic modeling technique. It represents the base of a Biomechanical reevaluation of these results, which consider the creation of an alternative cervical model created by Computer Tomography (CT) and a 3-D Scanner model ZCorp $700^{\circledR}$.

\subsection{Problem statement}

The importance of the human spine as the main distribution channel of the central nervous system and a correct mechanical integrity not only influences the stability of the body, but the way in which the loads are effectively transferred through it, in order to avoid a severe disability when a cervical injury takes place in one of the cervical vertebrae subjected to a compression beyond the stress limit of the vertebra (Fig. 1). An engineering analysis of this medical effect implies to consider the understanding of medical terminology, the way in which the natural and external forces are being transferred in a composite material. In this sense the mechanical properties of cortical and trabecular bone is required in order to build a 3-D model useful and precise to evaluate diverse procedures or surgical treatments in cervical lesions. It is important to establish that the interface between the skull and the thorax is known as the cervical spine (Fig. 2) and it is composed by 7 vertebrae ( $\mathrm{C} 1$ to $\mathrm{C} 7) . \mathrm{C} 1$ is called Atlas, which acts as the base of the skull, $\mathrm{C} 2$ allows the movement of the neck system, and it is referred to as the axis. Vertebrae C3 to C6 sustain the neck, transferring load from the skull to the thoracic vertebrae T1. The study of mechanical behavior and the analysis of the parametric cervical model were published by Beltran $[1,8,9]$ using classic 3-D modeling technique to get a preliminary model. The work was focused on the evaluation of a cervical plate OrtoSintese 4774/08 (55 mm) installed in the C3-C5 range of a patient, whose C4 vertebra was replaced using a bone graft taken from the iliac crest.

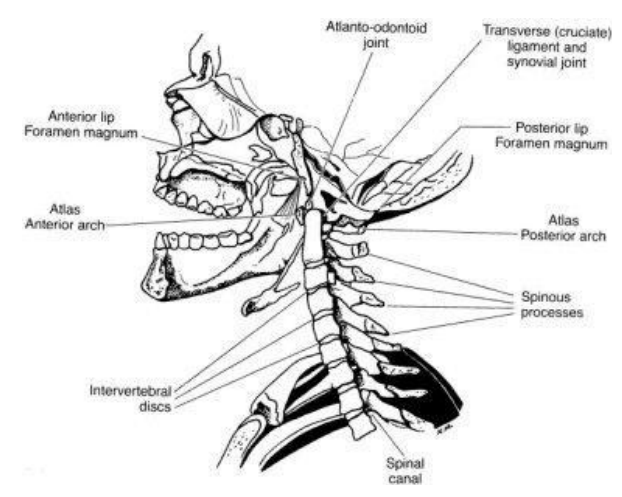

Fig. 1 Human Spine anatomy [18]

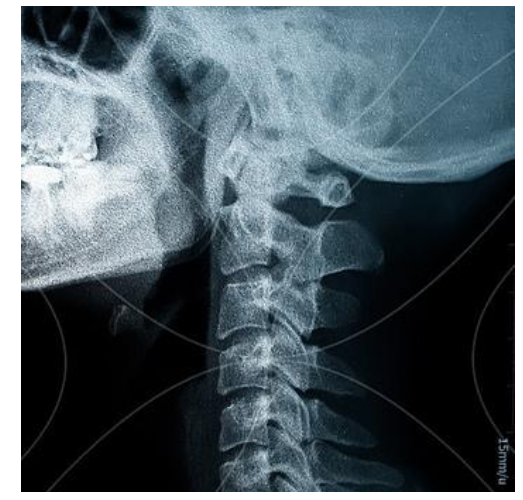

Fig. 2 Cervical Spine x-ray plate [19]

The plate was attached to the anterior surface of the spinal column, stabilizing and compressing the vertebrae surrounding the bone graft (Fig. 3). Finite Element Method was used for the numerical analysis. In this case, the present work shows comparative results using the same boundary conditions, using two different modeling techniques, 3-D Computed Tomography Scan and a 3-D Scanner, also a concise descriptive technique used on the developing of the models. 


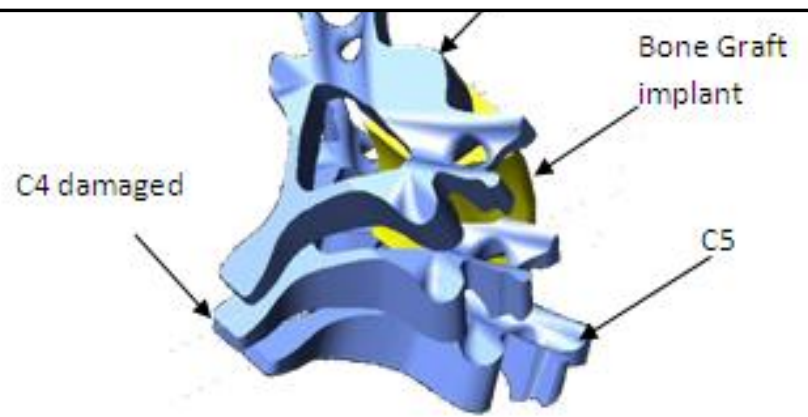

Fig. 3 CAD and FEM C3-C5 human model $[8,9]$

\subsection{Materials and Methods}

In order to reproduce the numerical models, an instrumented porcine cervical specimen with a bone graft and a cervical titanium plate was considered. Besides, a Scanner Z-Corp 700 and a CT Scanner Philips Brilliance was used in this process. In addition 3-D software as Pro-E Wildfire 4, ScanIP 3.1, UGS NX4, Geomagics R.10 and ANSYS R.10 were the base to create and simulate each numerical model. In this sense, it was necessary to consider the differences between the materials which are implied on the cervical porcine specimen, as in the figure 3 are shown.

\subsection{Modeling the cervical specimen using an Scan ZCorp 700}

A 3-D Scanner ZCorp 700 was used to model the cervical specimen. It allows digitalizing specifically irregular geometries as surfaces and the possibility to print quick prototypes. In this case, the specimen represents an ideal complexity in order to reproduce the loading conditions in the numerical model in order to evaluate specific loading conditions. Some advantages over the classic 2-D CAD are the easily operation of the hardware and software. high resolution to get porosity and details in organic specimens, specifically soft tissues and the structure of the bone, and the possibility to process STL (Stereolithography) files as universal format and to be processed as a faceted solid or shrink-wrapped. Furthermore, all the instructions suggested by ZCorp for the preliminary preparations for the specimen to be scanned are described in next points:

a) Calibration of the color of the specimen. It is preferred to use matte uniform colors.(Figure 5) [10]

b) Determination of the ideal distance to acquire data.

c) Level of noise in the data (e.g. dust).
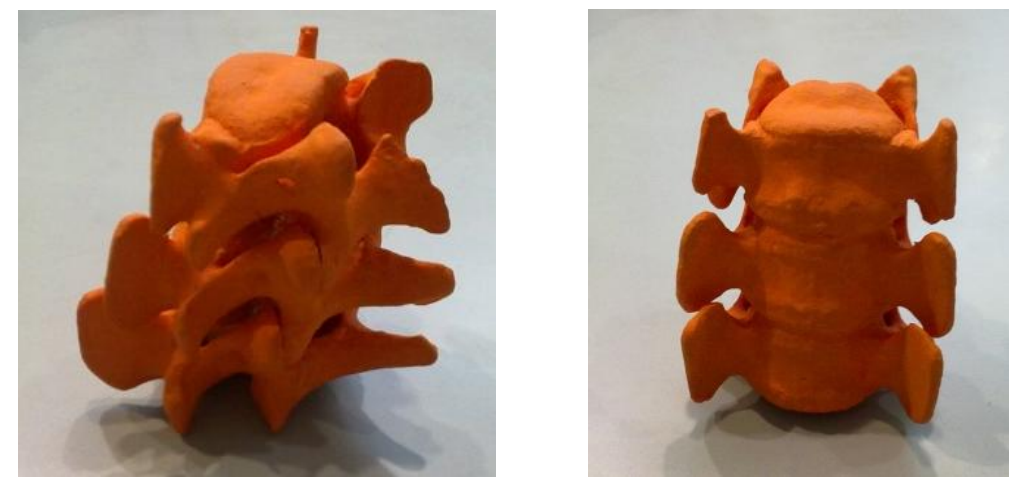

Fig. 5 Porcine Spine model with matte finishing.

There were used two methods to digitalize the specimen. The first one required a reference system in which the specimen was placed on (figure 6-a) and the second allowed to use reflective targets. A reflective effect is required on the scanning process and it was necessary to avoid that the laser ray of the scanner interacts over metallic surfaces with no painting cover, in this case in the inclusion of 
a titanium cervical plate (Figure 6-b). The influence of the deposition of powder on the geometry is barely perceptible $(0.017 \mathrm{~mm} / 0.0007 \mathrm{in})$. [11] In figure 6, the 3-D Reference system allows to scan main surfaces after to colors have been calibrated.

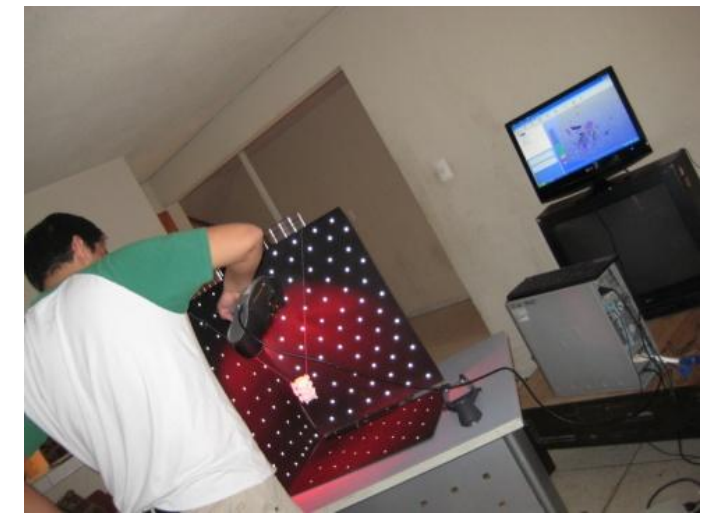

a)

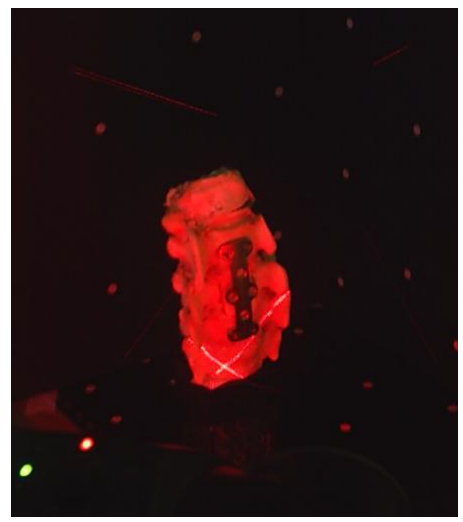

b)

Fig. 6 Three Dimensional Reference System to scan vertebral model and

However, a constant scanning over the surface of the specimen was necessary in order to keep the scanner laser into the reference system. It allows avoiding the inclusion of objects with similar colors in the scanning session. Another alternative to scan different kind of tissues is by the covering using diverse colors, as in the figure 7 is shown. In this figure, the porcine spine specimen [10] was digitalized and some of the surfaces had to be filled.

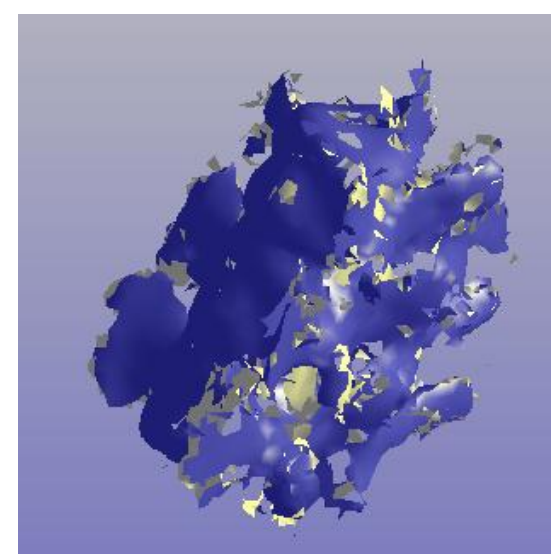

a) STL Surface

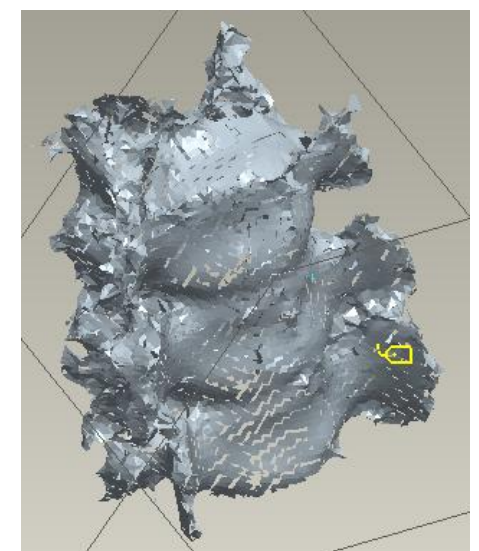

b) Faceted model (Shrink-wrapped)

Fig. 7 Partial view of the specimen with ZScan 700

\subsection{Comparison between the Scan IP 3.1 Software and Computer Tomography}

An ideal advantage of this method is the possibility to recreate in a digital format an in vivo specimen. In this case, for the medical team it is very important to interact with a precise and accurate model of cervical C3-C75, which was developed using computed tomography (CT) images and Scan IP 3.1 from DELCAM manufacturing. The construction of the detailed model included for each vertebra the anterior arch, odontoid process, superior and inferior articular facets, transverse processes, posterior arch and spinous process, considering a mesh with 3-D 8-node solid elements (solid 95). The scanning of the cervical specimen was done in a CT Scanner Philips Brilliance at "Hospital Regional $1^{\circ}$ de Octubre" including 126 CT images (separately each one $0.35 \mathrm{~mm}$ ) to be processed on ScanIP Software. Figure 8 shows an in vitro porcine specimen used in this study. Different tissues integrate the cortical and trabecular bone. 

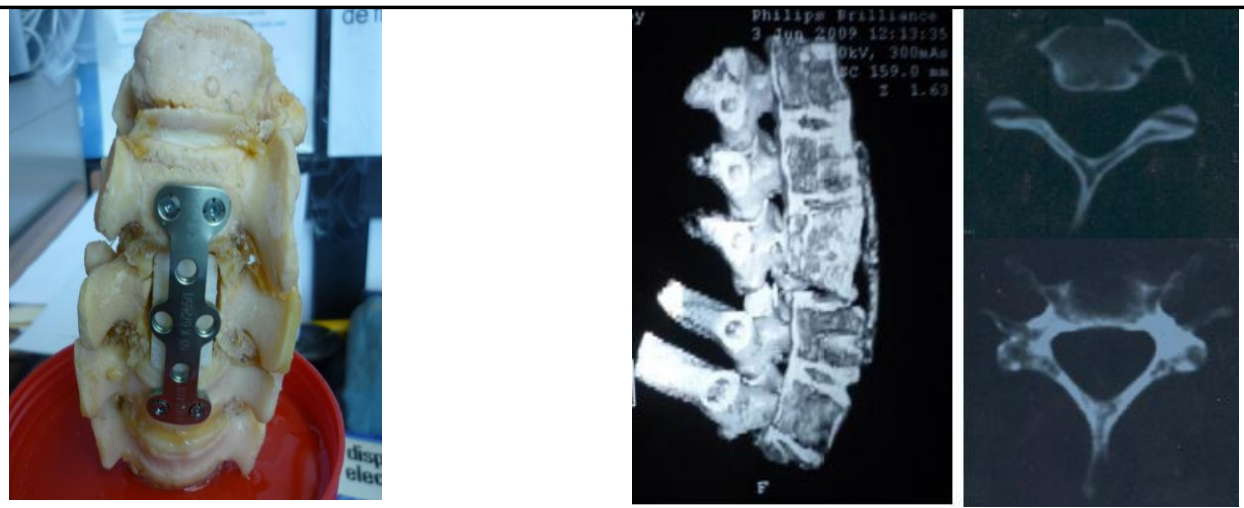

(a) In vitro porcine cervical specimen (b) Sagital and Lateral CT porcine cervical Fig. 8 Computer Tomography image for porcine cervical specimen

Once the 126 CT images were captured by the CT scanner, the output files (*.DICOM) had to be processed on ScanIP Software using the boundary of each density zone being clarified by diverse intensity color. It was necessary to assign different colors for each component in order to identify the elements detected by the Scanner. It is very important to mention that organic and non organic elements were integrated at the same session without any kind of covering as in the last method explained. Once the boundary was closed, the rest of the area was filled automatically. It represents an advantage in order to get the precisely profile of each section and globally for the cervical specimen.

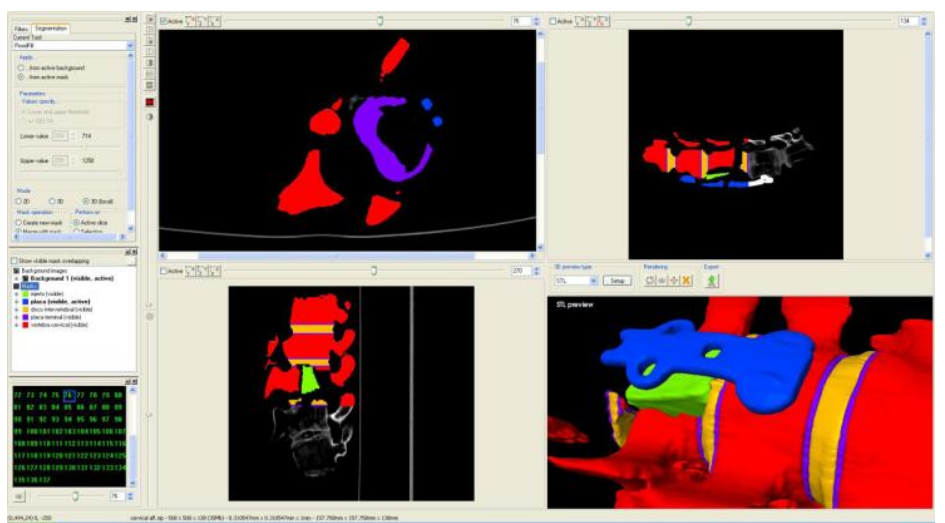

Fig. 9 ScanIP sketching - modeling process using CT image. [14]

Regardless of consider $0.35 \mathrm{~mm}$ between each CT image, some details were not possible to be developed efficiently, as in the figure 10 is shown. Specifically in the head of the screws (3317 Ortosintese) [13]. In base of the analysis of the specimen in the figure 10, the assigned colors for each part of the specimen are as follows: red for the cortical bone, green for the bone graft, blue for the cervical titanium plate and screws, yellow for the intervertebral disks and purple for the end disk laminate. It represents a useful tool in order to assign specific mechanical properties on FEM Software.

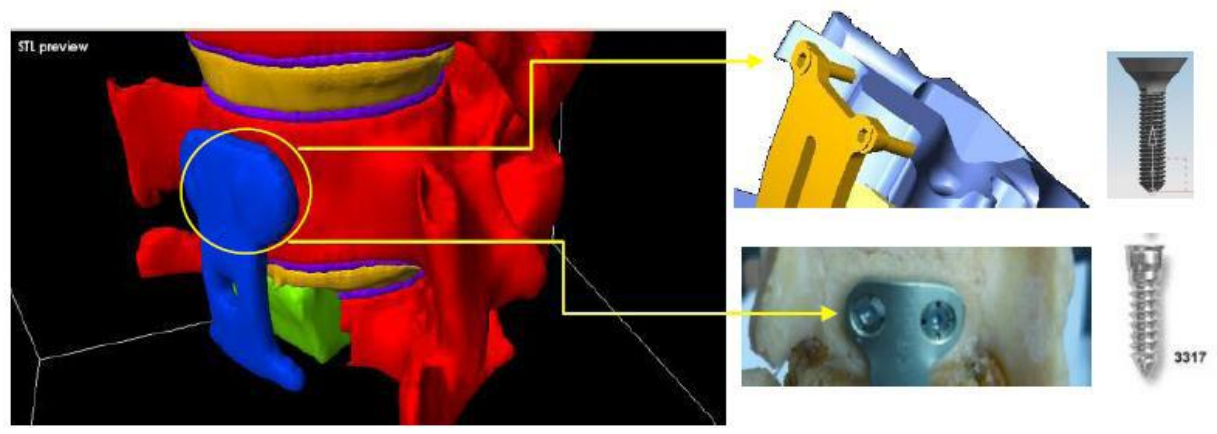

Fig. 10 Comparison between the CT image, CAD model and in vitro specimen. 
The resultant file after the full 3-D model has been developed is a STL (Stereolithography format), which can be processed as parametric format (Faceted model) in diverse software as Pro-Engineer 4.0 Wildfire, UGS-NX 5 or Geomagics R10. In the figure 11 the resultant 3-D model using de described technique is shown.
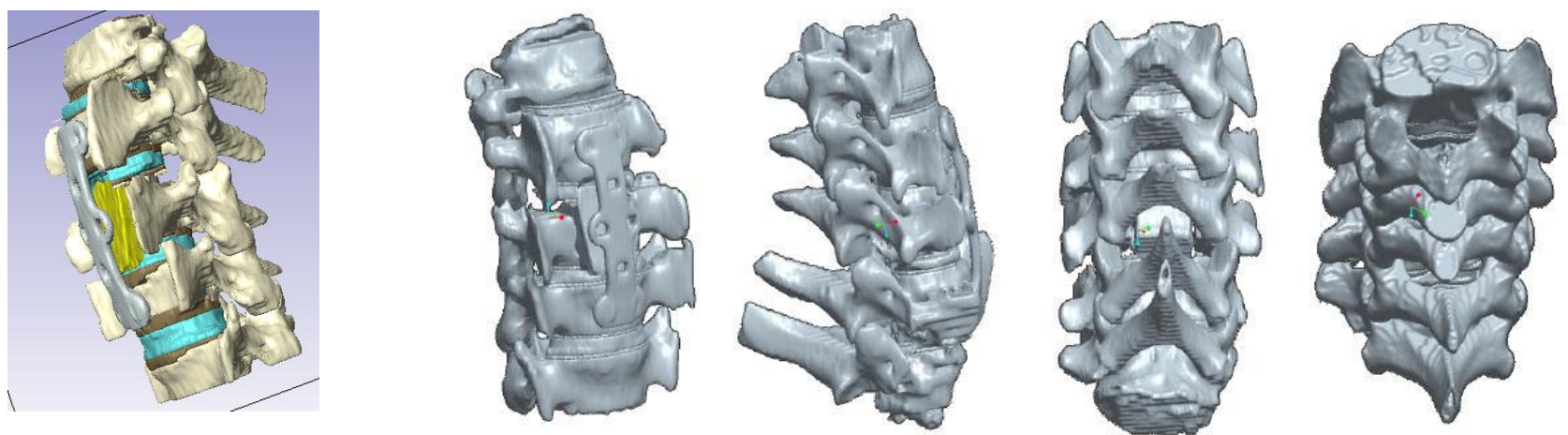

Fig. 11 Optimized CT - 3D Porcine Cervical Model.

\subsection{Analysis of the porcine cervical models}

The analysis of the advantages and disadvantages of the described methodologies, considers the easily to process the cervical specimen, the time to develop it, the affinity to the in vivo model and the number of tetrahedric elements in the meshing FEM process. (95782 elements on 157633 nodes for the classic CAD model [1,8], 543362 elements on 891106 nodes for the ZScan 700 method [This work], and 797871 elements on 1313094 nodes for the CT image 3-D and ScanIP [This work]). In all cases the specimen had to be assembled and the nodes of each element had to be shared in order to transfer the compression loading from the upper face of the first cervical and the lower face of the last. It is very important to mention that the most affinity to the in vivo specimen was found on the model processed with CT image 3-D and ScanIP. However, the number of elements increases considerably in comparison with the first models. Besides, the time to process each model depends on the ability to process in AutoCAD R17, Mechanical Desktop 6.0 [1,8] 30 2D tomographic slides, while in the last methods, for the Classic CAD, while for the ZCorp and CT image 3-D the process is optimized throughout the inclusion of ZScan - Pro-Engineer 4.0 Wildfire and ScanIP 3.1 - Pro-Engineer wildfire 4.0, Unigraphics NX - 5 and Geomagics R10.

\subsection{Boundary and loading conditions}

In order to accurately simulate the load transfer between the vertebrae, the bone graft and the cervical plate, it is highly important that the nodes, where the load is applied and transferred, coincide with each other. This validation was done on $[\mathbf{1 , 8}$. However, in the figures 12 and 13 the boundary and loading conditions used for each numerical specimen are indicated. The material properties considered for the three models are shown on the table 1. Each one of the finite element model was analyzed under the same boundary and loading conditions that the Classic 2-DCAD in order to evaluate the mechanical behavior.

Table 1. Material properties for the numerical analysis [12]

\begin{tabular}{|c|c|c|c|c|}
\hline & Property & Value & Units & Reference \\
\hline \multirow{2}{*}{ CORTICAL BONE } & Young Module & 12 & [GPa] & \multirow{6}{*}{ [12] } \\
\hline & Poisson Ratio & 0.2 & & \\
\hline BONE GRAFT & Compression Stress Strength & $5-15$ & {$[\mathrm{MPa}]$} & \\
\hline \multirow{3}{*}{$\begin{array}{l}\text { CERVICAL PLATE AND } \\
\text { 3317/04 OS (Ortosintese } \\
\text { Ti6A14V) }\end{array}$} & Young Module & 102 & {$[\mathrm{GPa}]$} & \\
\hline & Poisson Ratio & 0.3 & & \\
\hline & Yielding Stress Strength & 827 & {$[\mathrm{MPa}]$} & \\
\hline
\end{tabular}




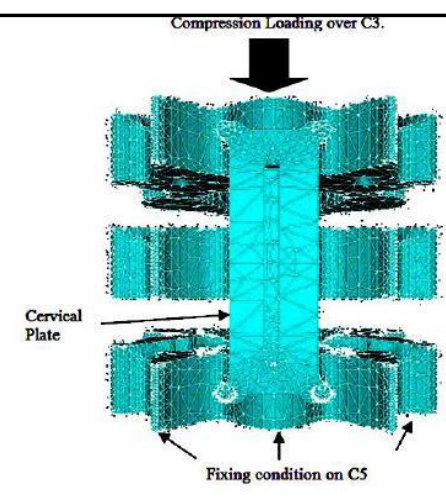

Fig. 12. Boundary conditions $[1,8]$.

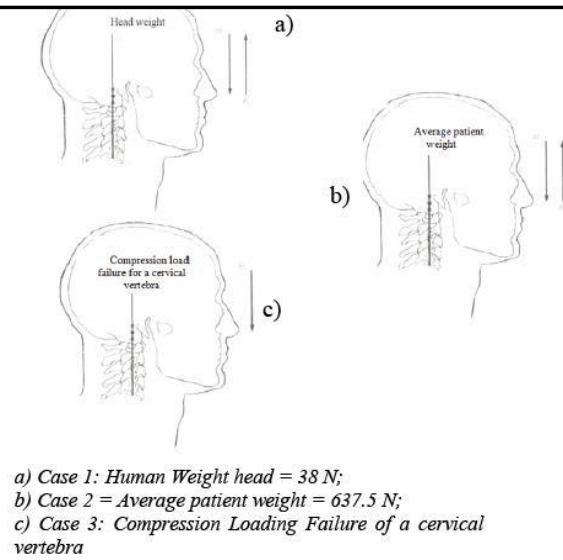

Fig. 13. Loading Conditions $[1,8]$

\subsection{Results}

The main results about numerical testing on each specimen are reported on the table 2 . It is important to take in count that preliminary publications about this research validated the surgery solution applied on the cervical range C3-C5 (Clinically called as Corporectomy), which allows to stabilize the instrumented zone after the fusion between the bone graft and the upper and lower surfaces of C3 and C5 respectively. It means that the bone graft had no significant displacements between its upper and lower surfaces. This is in accordance to the Muller criteria [15] which established that any cervical prosthesis should not be more than $3 \mathrm{~mm}$ in order to be considered a stable human spine after the surgery. Also the boundary conditions of the testing were described on [1, 8, and 9]. The results considering the loads, boundary conditions and FEM were solved with ANSYS 10.

Table 2. Numerical results comparison between CAD - ZCorp Scan and CT image models

\begin{tabular}{|c|c|c|c|c|c|c|}
\hline & Case of Study & Location & $\begin{array}{c}\text { CAD- } \\
\text { Specimen }\end{array}$ & $\begin{array}{c}\text { Zcorp-3-D } \\
\text { Scan model * }\end{array}$ & $\begin{array}{c}\text { CT image 3-D } \\
\text { Model }\end{array}$ & Notes \\
\hline \multirow{3}{*}{$\begin{array}{c}\text { Case } \\
1\end{array}$} & \multirow{2}{*}{ Maximum von Mises - Stress } & $\begin{array}{l}\text { The centre of the } \\
\text { cervical plate }\end{array}$ & $70.26 \mathrm{~Pa}$ & $68.9 \mathrm{~Pa}$ & $66.46 \mathrm{~Pa}$ & \multirow{3}{*}{$\begin{array}{l}* \text { For these } \\
\text { specimens, only } \\
\text { the surface was } \\
\text { created on the } \\
\text { Scan session. The } \\
\text { soft tissue } \\
\text { elements were } \\
\text { created on Pro-E } \\
4.0 \text { W.F }\end{array}$} \\
\hline & & $\begin{array}{l}\text { Around the hole of } \\
\text { the screws }\end{array}$ & $316.2 \mathrm{~Pa}$ & $303.7 \mathrm{~Pa}$ & $305.3 \mathrm{~Pa}$ & \\
\hline & $\begin{array}{c}\text { Maximum Displacement } \\
\text { between the bone graft and } \\
\text { upper and lower C } 3 \text { and C5 } \\
\text { vertebrae }\end{array}$ & $\begin{array}{l}\text { Interior surface of } \\
\text { C3, superior surface } \\
\text { of C5 adjacent to } \\
\text { the surfaces of the } \\
\text { bone graft }\end{array}$ & $\begin{array}{c}4.752 \mathrm{e}-4 \\
\mathrm{~mm}\end{array}$ & $4.397 \mathrm{e}-4 \mathrm{~mm}$ & $3.487 \mathrm{e}-4 \mathrm{~mm}$ & \\
\hline \multirow[b]{3}{*}{$\begin{array}{c}\text { Case } \\
2\end{array}$} & Maximum von Mises - Stress & $\begin{array}{l}\text { The centre of the } \\
\text { cervical plate }\end{array}$ & $662.8 \mathrm{~Pa}$ & $648.7 \mathrm{~Pa}$ & $635.7 \mathrm{~Pa}$ & \multirow[b]{3}{*}[1,8]{} \\
\hline & \multirow[b]{2}{*}{$\begin{array}{c}\text { Maximum Displacement } \\
\text { between the bone graft and } \\
\text { upper and lower C } 3 \text { and C5 } \\
\text { vertebrae }\end{array}$} & $\begin{array}{l}\text { Around the hole of } \\
\text { the screws }\end{array}$ & $3351.7 \mathrm{~Pa}$ & $3329.6 \mathrm{~Pa}$ & $3312.2 \mathrm{~Pa}$ & \\
\hline & & $\begin{array}{l}\text { Interior surface of } \\
\text { C3, superior surface } \\
\text { of C5 adjacent to } \\
\text { the surfaces of the } \\
\text { bone graft }\end{array}$ & $0.0054 \mathrm{~mm}$ & $0.0042 \mathrm{~mm}$ & $0.0039 \mathrm{~mm}$ & \\
\hline \multirow[b]{3}{*}{$\begin{array}{c}\text { Case } \\
3\end{array}$} & \multirow{2}{*}{ Maximum von Mises - Stress } & $\begin{array}{l}\text { The centre of the } \\
\text { cervical plate }\end{array}$ & $7.025 \mathrm{MPa}$ & $6.96 \mathrm{MPa}$ & $6.92 \mathrm{MPa}$ & \multirow[b]{3}{*}[1,8,14]{} \\
\hline & & $\begin{array}{l}\text { Around the hole of } \\
\text { the screws }\end{array}$ & $328.2 \mathrm{MPa}$ & $317.8 \mathrm{MPa}$ & $302.6 \mathrm{MPa}$ & \\
\hline & $\begin{array}{c}\text { Maximum Displacement } \\
\text { between the bone graft and } \\
\text { upper and lower C } 3 \text { and C5 } \\
\text { vertebrae }\end{array}$ & $\begin{array}{l}\text { Interior surface of } \\
\text { C3, superior surface } \\
\text { of C5 adjacent to } \\
\text { the surfaces of the } \\
\text { bone graft }\end{array}$ & $0.0546 \mathrm{~mm}$ & $0.0483 \mathrm{~mm}$ & $0.0411 \mathrm{~mm}$ & \\
\hline
\end{tabular}




\section{Conclusions}

Engineering evaluation of the medical solutions on the orthopaedic area allows knowing the Biomechanical behavior of the involved structures. [17] In this case, the prosthesis of bone graft contributes to the human stability after the fusion process between the vertebral bodies of $\mathrm{C} 3$ and C5. The results of the numerical simulation are in accordance with experimental testing. This is one of the most recommendable methodologies that medics and hospitals have approved. Besides, the use of porcine specimens taking in count similarities between human vertebrae, specifically in mechanical properties; allows validating numerical models in order to study the mechanical behavior prior to be tested in human patients. Finally, the results of the table 2 show a convergence between the critic points using diverse modeling techniques. In each case, the von Misses stresses and the maximum displacements are lower for the CT image 3-D Model than the CAD and ZCorp 3-D Scanner. This compliance is in accordance to the process to conform each cervical model, the accuracy of each method, the quality of each mesh for the numerical model and the similarity to the in vivo specimen, because of the inclusion of the bone density in the Computed Tomography. Therefore, the results were validated in base of experimental testing and the analysis and approbation of the medical team, in this case, specialists on spine surgery which are responsible to fix each component and support of the prosthesis.

\section{Acknowledges}

The authors kindly acknowledge the grants given by the National Council for Science and Technology, CONACYT, Mexico and the National Polytechnic Institute and the support given to this project by ISSSTE Hospital $1^{\circ}$ de Octubre for the means and facilities for the development of this research. Project No. (IPN) SIP20091599. We also acknowledge the invitation to the 2010 BSSM International Conference on Advances in Experimental Mechanics and especially to the organizing Committee.

\section{References}

[1] J.A. Beltrán-Fernández \& et. Al, "Modelling of a Cervical Plate and Human Cervical Section C3 - C5 under Compression Loading Conditions Using the Finite Element Method, Transtech publications “Applied Mechanics and Materials", Vols. 13-14-2008 p.p. 49-56, UK.

[2] Huiskes R, Chao EYS. A survey of finite element analysis in orthopaedic biomechanics: the first decade. Journal of Biomechanics 16: 385-409, 1983.

[3] Prendergast PJ. Finite element models in tissue mechanics and orthopaedic implant design. Clinical Biomechanics 12: 343-366, 1997

[4] Holzpafel GA, Ogden RW, Eds. Mechanics of Biological Tissues. Springer, Berlin, 2006

[5] Lally C, Kelly DJ, Prendergast PJ. Stents, In Wiley Encyclopedia of Biomedical Engineering, (Ed.: M.Akay), John Wiley \& Sons, Vol. 5, pp. 3345-3355, 2007.

[6] Van der Meulen MCH, Huiskes R. "Why mechanobiology?" A survey article. Journal of Biomechanics 35: 401-414, 2002.

[7] Panjabi M M; Pelker R R; Friedlaender G E; Markham T C;; Moen C J Effects of freezing and freeze-drying on the biomechanical properties of rat bone. Journal of orthopaedic research: official publication of the Orthopaedic Research Society 1984; 1(4):405-11.

[8] Beltrán-Fernández JA \& et.al., "Mechanical Behavior of a Calcium Phosphate Ceramic Bone Graft used in the Rehabilitation of a C4 Human Vertebra", published by Transtech in "Applied Mechanics and Materials". 5th BSSM International Conference on Advances in Experimental Mechanics, University of Manchester, UK, 4-6 September 2007. 
[9] J. A. Beltrán Fernández, L. H. Hernández Gómez, G. Urriolagoitia Calderón, M. Dufoo Olvera and A. González Rebatú, "Distribución de esfuerzos por la acción de cargas de compresión en la vértebra cervical C5, empleando el Método del Elemento Finito" Científica, Vol. 9, núm. 3, Julio-Septiembre del 2005, ISSN 1665-0654, 135-142.

[10] R. Rodríguez-Cañizo, L. Hernández-Gómez, J. Beltrán-Fernández, G. Urriolagoitia-Calderón, M. Dufoo-Olvera, Análisis biomecánico de un disco intervertebral porcino lesionado - estudio experimental, $8^{\circ}$ CONGRESO IBEROAMERICANO DE INGENIERÍA MECÁNICA, (Cusco, Perú), 23 al 25 de Octubre, (2007).

[11] Zcorp, Self-Positioning Handheld 3D Scanner, Method Sheet: Scanning Multi-colored or Multi-shaded Part, Document: MS020016 (2007).

[12] J.A Beltrán-Fernández, Análisis numérico de las cervicales C3 - C7 asociado al problema del latigazo cervical, Tesis de Doctorado, Sección de Estudios de Posgrado e Investigación, ESIME Zacatenco, México. (2007)

[13] Ortosintese (2006), Catálogo de productos 2006, Rua Friedrich Von Voith, 896 - Jaragua, Brasil.

[14] Ruíz-Muñoz, E.R, Beltrán-Fernández, J.A \& Et al, “Técnicas de modelado en 3D aplicado a casos de vértebras porcinas por medio de un escáner 3D y tomografías.”, XXV Congreso Nacional De Investigación Biomédica, Universidad Autónoma de Nuevo León, Facultad de Medicina, 2009.

[15] Allen, B., Ferguson, R., Et. al. (1982), A mechanistic classification of closed, indirect fractures and dislocations of the lower cervical spine, J. of Spine, vol. 7, p.p. $1-27$.

[16] J.A. Beltran-Fernández, L.H. Hernández-Gómez, G. Urriolagoitia-Sosa, A. González-Rebatú, G. Urriolagoitia-Calderón, (2009) Biomechanical evaluation of a C3-C5 human cervical model created by computer tomography $\mathrm{CT}$ and 3-D scan under compression loading. 3rd International Conference on Advanced Computational Engineering and Experimenting (ACEX-2009), Grand Hotel Palazzo Carpegna, Via Aurelia, 481 - 00165 (Rome, Italy). Organised by The Italian Association for Stress Analysis/ Department of Applied Mechanics / Seconda Universita' degli Studi di Napoli / Prof. Dr.-Ing Andreas Öchsner (chair), 22-23 June - 2009

[17] Ruíz-Muñoz, ER1, Beltrán-Fernández, JA, Rodríguez-Cañizo, RG, Hernández-Gómez LH, González-Rebatú A, (2009) "Análisis de la estabilización segmentaria en especímenes de columna lumbar porcina L3-L5, con cerclaje interespinoso empleando collarines de poliamida 6/6". IX CONGRESO IBEROAMERICANO DE INGENIERIA MECANICA, CIBIM 09. FEIBIM - Federación Iberoamericana de Ingeniería Mecánica, Escuela Técnica Superior de Ingenieros Industriales de la Universidad de las Palmas de Gran Canaria, España. 17-20 Noviembre, 2009.

[18] Bland JH. Disorders of the cervical spine, diagnosis and medical management. 2nd ed. Philadelphia: WB Saunders; 1994.

[19] Information on http://www.shutterstock.com/pic-31223248-X-ray-image-of-cervicalvertebra.html 